\title{
Evaluation of Fungicides and Bioagents against Fusarium proliferatum under In vitro by Spore Germination Inhibition Technique
}

\begin{abstract}
Background: Bottle gourd is a cucurbitaceous vegetable of culinary and medicinal importance cultivated in various tropical and subtropical regions of world. This crop is exposed to a wide variety of seed and soil mycoflora, out of which Fusarium proliferatum is utmost important as far as seed germination, viability and seedling vigour are concerned.

Methods: Study was taken up to evaluate different fungicides and bioagents for their efficacy against the fungus Fusarium proliferatum under in vitro through spore germination inhibition technique.

Result: Spore germination inhibition of $86.00 \%, 85.00 \%$ and $81.33 \%$ was recorded with hexaconazole $(5 \% \mathrm{SC}) @ 0.2 \%\left(\mathrm{C}_{3}\right)$, mancozeb (75\% WP) @ 0.3\% $\left(\mathrm{C}_{3}\right)$ and Pseudomonas fluorescens (1\% WP) @ 2\% $\left(\mathrm{C}_{3}\right)$, respectively. The inhibition in spore germination by mancozeb (75\% WP) and Pseudomonas fluorescens (1\% WP) was upto $77.33 \%$ and it was $61.78 \%$ and $67.33 \%$ in treatments involving carbendazim (50\% WP) and Trichoderma harzianum (1\% WP) that could be exploited to devise integrated approach for disease management.
\end{abstract}

Key words: Bioagents, Bottle gourd, Cucurbits, Fungicides, Fusarium proliferatum.

\section{INTRODUCTION}

Bottle gourd is known to be an important vegetable crop grown globally in various tropical and sub-tropical regions including India, Srilanka, China and Bangladesh (Avinash and Rai, 2013; Saha et al. 2016). The crop has high amount of protein, carbohydrates and water present in it and the aerial parts are usually consumed as vegetable (Abushaala et al. 2016). Each and every part of crop is of medicinal importance and it is used particularly for its diuretic properties in India, Brazil and European countries (Minocha, 2015). Amongst large number of cucurbits grown, bottle gourd is mainly a crop in northern parts of India especially during summer and rainy seasons (Chauhan and Bhatia, 2013). The crop is exposed to a wide variety of fungal, bacterial and viral pathogens in addition to seed and soil borne pathogens (Maheshwari et al. 2013). Seed borne pathogens present internally or externally on seed as a contaminant can reduce seed germination, viability and seedling vigour (Abdelwehab et al. 2014). In the earlier studies, Fusarium proliferatum was found as major seed borne pathogen affecting seed germination, seedling vigour and seed viability of bottle gourd (Soni, 2018).

Disease development in any crop depends on various factors and is directly proportional to pathogen spore population (Mukund, 2006). In order to manage plant diseases, spore population must be minimized to a certain level for which farmers usually rely on agrochemicals as they offer a quick and effective solution to pests and diseases but chemical fungicides often result in problems of toxic residue, resistance development, environmental pollution and health hazards (Begum et al. 2010; Anand and Bhaskaran,
Department of Plant Pathology, Chaudhary Charan Singh Haryana Agricultural University, Hisar-125 004, Haryana, India.

Corresponding Author: Namita Soni, Department of Plant Pathology, Chaudhary Charan Singh Haryana Agricultural University, Hisar-125 004, Haryana, India. Email: namitasoni15@gmail.com

How to cite this article: Soni, N., Raj, K. and Vijaykumar, S. (2021). Evaluation of Fungicides and Bioagents against Fusarium proliferatum under In vitro by Spore Germination Inhibition Technique. Indian Journal of Agricultural Research. DOI: 10.18805/ IJARe.A-5842.

Submitted: 04-06-2021 Accepted: 01-10-2021 Online: 16-11-2021

2009). Considering the health benefits of bottle gourd and its domestic usage as a vegetable, it is high time to reduce fungicidal application in crop through feasible substitution with bioagents in order to reduce potential health hazards caused due to usage of synthetic pesticides (Pipliwal et al. 2015). Bioagents have been lately known for induction of systemic resistance against a number of plant diseases and are being widely used in agri-horticultural ecosystem as plant protectants (Ramamoorthy et al. 2001; Tripathi et al. 2020). The most common bioagents include Trichoderma viride, $T$. harzianum, Pseudomonas fluorescens, Bacillus subtilis and Gliocladium virens which act as efficient antagonists against a wide variety of plant pathogens (Sultana and Ghaffar, 2010; Tripathi et al. 2020). Keeping this in view the impact of Fusarium proliferatum on seed germination, seedling vigour and seed viability, the present study was aimed at optimizing different concentrations of plant protectants (fungicides and bioagents) for their efficacy against the fungus under in vitro 
through spore germination inhibition technique and compare the efficacy of bioagents to synthetic chemicals so as to devise suitable eco-friendly alternative management strategies against Fusarium proliferatum.

\section{MATERIALS AND METHODS}

The fungal culture Fusarium proliferatum isolated from seeds and fruits of bottle gourd was used in the present investigation on evaluation of various fungicides and bioagents by spore germination inhibition technique. Fusarium proliferatum was maintained on potato dextrose agar slants and subcultured at regular intervals (fortnightly) (Plate 1).

The experiment on spore germination inhibition was conducted in Department of Plant Pathology, CCS Haryana Agricultural University, Hisar, Haryana. Different fungicides and bioagents were evaluated under in vitro against the seed borne pathogen, Fusarium proliferatum by using spore germination inhibition method. Each fungicide and bioagent was used at three different concentrations, viz., optimum concentration $\left(\mathrm{C}_{2}\right)$, concentration < optimum $\left(\mathrm{C}_{1}\right)$ and concentration > optimum $\left(\mathrm{C}_{3}\right)$ (Table 1$)$. The apparatus used

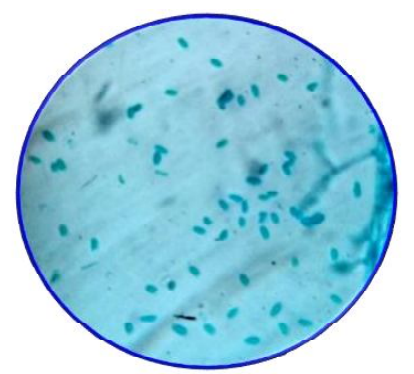

A. Microconidia

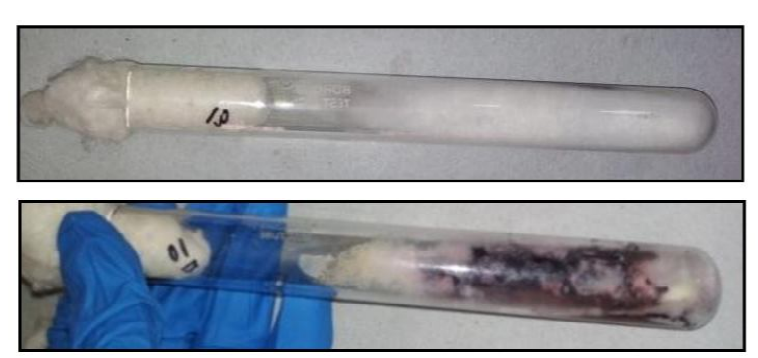

C. Test pathogen

Plate 1: Macroconidia, microconidia and vegetative culture of Fusarium proliferatum.

Step 1

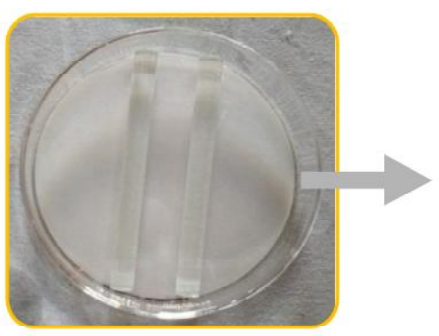

Step 2

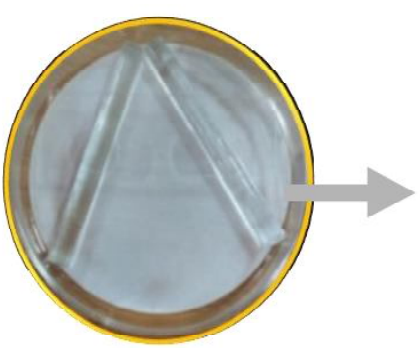

Step 3

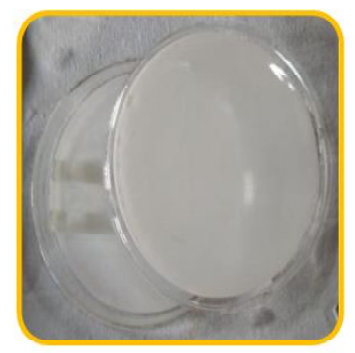

Plate 2: Spore germination inhibition assay under in vitro conditions by cavity slide technique. 
Based on per cent spore germination, spore germination inhibition against each treatment was calculated as per Vincent, (1947):

$$
I=\frac{C-T}{C} \times 100
$$

Where,

$\mathrm{I}=$ per cent inhibition; $\mathrm{C}=$ spore germination in control and

$\mathrm{T}=$ spore germination in treatment.

\section{RESULTS AND DISCUSSION}

The evaluation of three systemic fungicides [Carbendazim ( $50 \%$ WP), Propiconazole (25\% EC), Hexaconazole (5\% SC)] and two non-systemic fungicides [Mancozeb (75\% WP) and Copper oxychloride (50\% WP)] alongwith two bioagents [Trichoderma harzianum (1\% WP) and Pseudomonas fluorescens (1\% WP)] for their efficacy against seed borne pathogen Fusarium proliferatum (Table 2) revealed that maximum inhibition in spore germination was $86.00 \%, 85.00$ $\%$ and $81.33 \%$ due to Hexaconazole (5\% SC) @ 0.2\% $\left(\mathrm{C}_{3}\right)$, Mancozeb (75\% WP) @ 0.3\% ( $\left.\mathrm{C}_{3}\right)$ and Pseudomonas fluorescens (1\%WP) @ 2\% $\left(\mathrm{C}_{3}\right)$, respectively (Table 2$)$. These results were found at par with each other but were significantly different as compared to control. The lower spore germination inhibition of $56.00 \%, 59.67 \%$ and $64.33 \%$ was observed in Carbendazim (50\%WP) @ 0.05\%, Hexaconazole (5\% SC) @ 0.05\% and Trichoderma harzianum (1\%WP) @ 0.3\%, respectively. Maximum mean spore germination was observed in mancozeb (75\% WP) and Pseudomonas fluorescens (1\% WP) upto $77.33 \%$ with lower value of $61.78 \%$ and $67.33 \%$ in treatments involving carbendazim (50\% WP) and Trichoderma harzianum (1\% WP), respectively (Fig 1).

Among the systemic fungicides, significantly higher spore germination inhibition was observed in case of Propiconazole $25 \%$ EC whereas out of non-systemic fungicides evaluated, Mancozeb $75 \%$ WP was found to have higher efficacy. The efficacy of two non-systemic fungicides, Mancozeb 75\% WP and Copper oxychloride 50\% WP was however, significantly at par with each other. Among the bioagents evaluated for their efficacy on spore germination inhibition, Pseudomonas fluorescens 1\% WP gave better results over Trichoderma harzianum 1\% WP. On an average,

Table 1: Evaluation of fungicides and bioagents against Fusarium proliferatum by spore germination inhibition technique.

\begin{tabular}{lccr}
\hline Fungicides/ & \multicolumn{3}{c}{ Concentration (\%) } \\
\cline { 2 - 4 } Bioagents & $\mathrm{C}_{1}$ & $\mathrm{C}_{2}$ & $\mathrm{C}_{3}$ \\
\hline Carbendazim 50\% WP & 0.05 & 0.1 & 0.2 \\
Mancozeb 75\% WP & 0.10 & 0.2 & 0.3 \\
Propiconazole 25\% EC & 0.05 & 0.1 & 0.2 \\
Hexaconazole 5\% SC & 0.05 & 0.1 & 0.2 \\
Copper oxychloride 50\% WP & 0.10 & 0.2 & 0.3 \\
Pseudomonas fluorescens 1\% WP & 0.50 & 1.0 & 2.0 \\
Trichoderma harzianum 1\% WP & 0.30 & 0.4 & 0.5 \\
\hline
\end{tabular}

Control [Equal volume of sterile distilled water (SDW)].

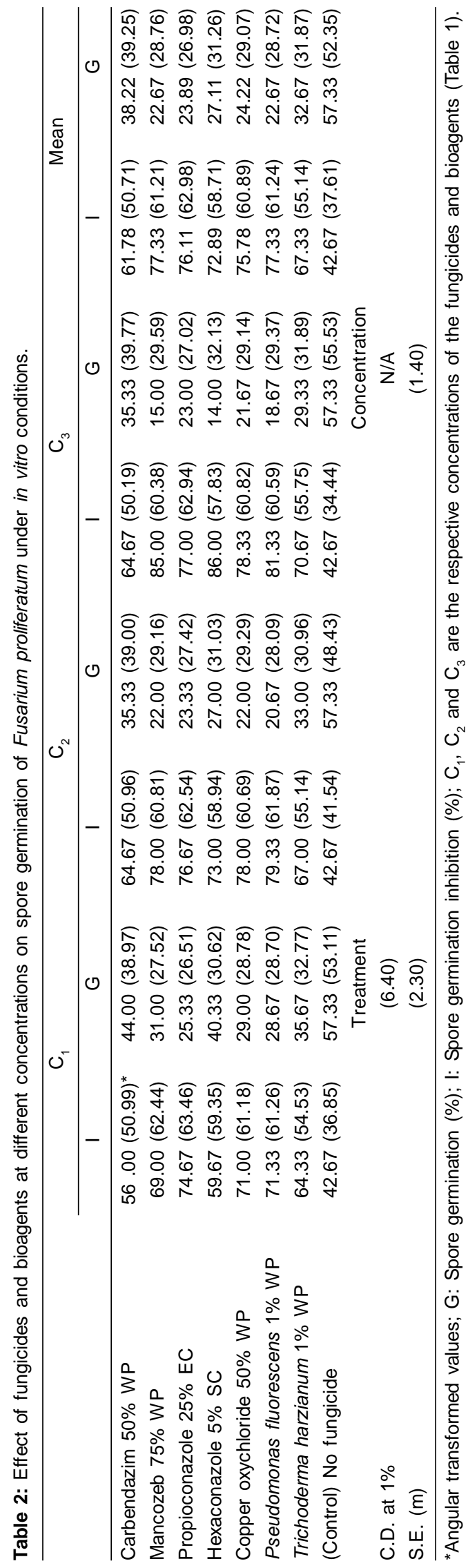




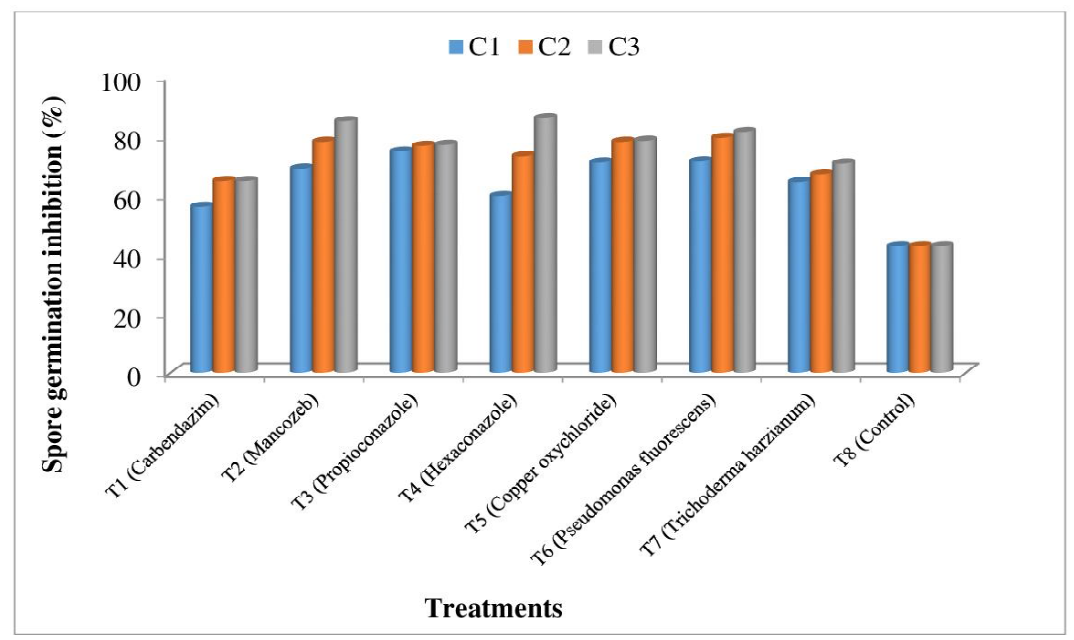

Fig 1: Effect of fungicides and bioagents on inhibition of spore germination of Fusarium proliferatum.

the efficacy of Mancozeb 75\% WP, Pseudomonas fluorescens $1 \%$ WP and Propiconazole 25\% EC was the highest among all the fungicides and bioagents evaluated but significantly at par with each other. The results of present study are similar to the findings of other researchers. Anand and Bhaskaran (2009) studied eight antagonistic bioagents for ecofriendly management of chilli fruit rot caused by Colletotrichum capsici and Alternaria alternata and found Pseudomonas fluorescens and Trichoderma isolate 3 was effective in inhibiting pathogens. Similarly the results of various researchers are also corroborative to our observations regarding Pseudomonas fluorescens as effective bioagent (Leeman et al 1995, Nayaka et al 2009).

Nisa et al. (2011) tested systemic and non-systemic fungicides, viz., carbendazim, myclobutanil, bitertanol, hexaconazole, mancozeb, captan and zineb for their effect on mycelial growth and spore germination of Fusarium oxysporum under in-vitro and observed significant germination inhibition with mancozeb followed by captan and zineb amongst non-systemic fungicides.

Dar et al. (2013) evaluated nine fungicides (carbendazim, hexaconazole, thiophanate methyl, triadimefan, metalaxyl, mancozeb, captan, copper oxychloride and chlorothalonil) and seven bioagents (Trichoderma harzianum, Trichoderma virens, Lacaria laccata, Boletus edulis, Suillus placids and Russula lutea) under in vitro for their efficacy towards inhibition of mycelial growth and spore germination in Fusarium oxysporum $f$. sp. pini through dual culture and culture filtrate technique. Maximum spore germination inhibition was shown by mancozeb $75 \%$ WP treatment among non-systemic fungicides and carbendazim 50\% WP among systemic fungicides and Trichoderma harzianum $1 \%$ WP was observed to exhibit best results as compared to filtrates of other biocontrol agents.

\section{CONCLUSION}

The spore germination of Fusarium proliferatum, a prominent seed borne pathogen associated with seeds and fruits of bottle gourd was inhibited by mancozeb $75 \%$ WP and Pseudomonas fluorescens 1\% WP upto $77.33 \%$ that was $61.78 \%$ and $67.33 \%$ in treatments involving carbendazim $50 \%$ WP and Trichoderma harzianum 1\% WP that could be exploited to devise integrated approach for disease management.

\section{Source of funding}

CCS Haryana Agricultural University, Hisar 125001 (Haryana, India) provided necessary funds for successful completion of research work.

\section{REFERENCES}

Abdelwehab, S.A., El-Nagerabi, S.A.F. and Elshafie, A.E. (2014). Mycobiota associated with imported seeds of vegetable crops in Sudan. The Open Mycology Journal. 8: 156-173.

Abushaala, F.A., Ashour, A.O., Ramadan, A.R.B. and Alkeskas, A.A. (2016). Investigation of seed-borne fungi associated with cucurbit seeds in two different regions of Libya. Al-satil. 10(15): 37-53.

Anand, T. and Bhaskaran, R. (2009). Exploitation of plant products and bioagents for ecofriendly management of chilli fruit rot disease. Journal of Plant Protection Research. 49(2): 195-203.

Avinash, T.S. and Rai, V.R. (2013). Identification of diverse fungi related with selected cucurbitaceous vegetables. Journal of Agricultural Technology. 9(7): 1837-1848.

Begum, M.F., Mahal, M.F. and Alam, M.S. (2010). Inhibition of spore germination and mycelial growth of three fruit rot pathogens using some chemical fungicides and botanical extracts. Journal of Life and Earth Science. 5: 23-27.

Chauhan, R.S. and Bhatia, J.N. (2013). Screening of bottle gourd genotypes against anthracnose disease under natural as well as artificial epiphytotic conditions. Plant Disease Research. 28(1): 92-93.

Dar, W.A., Beig, M.A., Ganie, S.A., Bhat, J.A., Rehman, S.U. and Razvi, S.M. (2013). In vitro study of fungicides and biocontrol agents against Fusarium oxysporum $f$. sp. pini causing root rot of Western Himalayan fir (Abies pindrow). Scientific Research and Essays. 8(30): 1407-1412. 
Kiraly, Z., klement, S.J., Voros and Solymosy, K. (1974). Methods in Plant Pathology with Special Reference to Breeding for Resistance. Elsevier Scientific Publishing Company. New York.

Leeman, M., VanPelt, J.A., Hendrickx, M.J., Scheffer, R.J., Bakker, P.A.H.M. and Schippers, B. (1995). Biocontrol of Fusarium wilt of Radish in commercial greenhouse trials by seed treatment with Pseudomonas fluorescens WCS374. Journal of Phytopathology. 85(10): 1301-1305.

Maheshwari, S.K., Choudhary, B.R. and Singh, D. (2013). Occurrence of fungal diseases of bottle gourd in Rajasthan. Progressive Horticulture. 45(1): 206-208.

Minocha, S. (2015). An overview on Lagenaria siceraria (bottle gourd). Journal of Biomedical and Pharmaceutical Research. 4(3): 4-10.

Mukund, B. (2006). Epidemiology and management of anthracnose of bottle gourd caused by Colletotrichum lagenarium (Pass.) Ell. and Halst. M.Sc. thesis, Chaudhary Charan Singh Haryana Agricultural University, Hisar.

Nayaka, S.C., Shankar, A.C.U., Reddy, M.S., Niranjana, S.R., Prakash, H.S., Shetty, H.S. and Mortensen, C.N. (2009). Control of Fusarium verticillioides, cause of ear rot of maize, by Pseudomonas fluorescens Pest Management Science. 65(7): 769-775.

Nisa, T.U., Wani, A.H., Bhat, M.Y., Pala, S.A. and Mir, R.A. (2011). In vitro inhibitory effect of fungicides and botanicals on mycelia growth and spore germination of Fusarium oxysporum. Journal of Biopesticides. 4(1): 53-56.
Pipliwal, S.K., Jadeja, K.B., Sharma, A. and Dhakad, J.K. (2015). Effect of bioagents on spore germination of Alternaria burnsii. The Bioscan. 10(4): 1759-1762.

Ramamoorthy, V., Viswanathan, R., Raguchander, T., Prakasan, V. and Samiyappan, R. (2001). Induction of systemic resistance by plant growth promoting rhizobacteria in crop plants against pests and diseases. Crop Protection. 20: 1-11.

Saha, A., Das, S., Chakraborty, P., Saha, B., Saha, D. and Saha, A. (2016). Two new bottle gourd fruit rot causing pathogens from Sub Himalayan West Bengal. Journal of Agricultural Technology. 12(2): 337-348.

Soni, N. (2018). Investigations on fruit and seed mycoflora of bottle gourd and its management. M.Sc. thesis, Chaudhary Charan Singh Haryana Agricultural University, Hisar.

Sultana, N. and Gaffar, A. (2010). Effect of fungicides, microbial antagonists and oilcakes in the control of Fusarium solani, the cause of seed rot, seedling and root infection of bottle gourd, bitter gourd and cucumber. Pakistan Journal of Botany. 42(4): 2921-2934.

Tripathi, A.N., Meena, B.R., Pandey, K.K. and Singh, J. (2020). Microbial bioagents in agriculture: Current status and prospects. New Frontiers in Stress Management for Durable Agriculture. 331-368.

Vincent, J.M. (1947). Distortion of fungal hyphae in the presence of certain inhibitors. Nature. 15: 850. 